\title{
Truth Believers and True Believers: The Conditional Effects of Voluntary Associations on the Political Participation of Black Americans
}

\author{
Randall D. Swain and Maruice Mangum
}

Using data from the 1996 National Black Election Study, this investigation examines the impact of two kinds of voluntary associations on electoral and non-electoral political participation among Black Americans. It does so by examining the church's context or environment and membership in organizations. We report several significant findings. First, both types of voluntary associationschurch and secular organizational membership — are positive influences on both forms of political participation. Second, memberships in secular organizations are more influential facilitators of activism among Black Americans than the church. Third, the type of voluntary association matters in terms of the kinds of political activities promoted. The church promotes political activities that call for less energy and less resources. Membership in secular organizations is related to high-intensity forms of political activity.

Voluntary associations are social groups that provide members with opportunities to meet with other like-minded people (Hoggett and Bishop 1986) and allow them to participate in efforts to realize the group's benefit by working together (Lopata 1965). Voluntary associations have a general consensus on goals and purposes, and members work to promote and defend their interests (Streeck and Schmitter 1991). These organizations are typically identified by their manifest, and sometimes latent, goals (Brown 1979).

Tocqueville ([1835] 2001) recognized the propensity of Americans to join many groups and voluntary associations such as churches (used interchangeably with religious associations) and those not related to the church (used interchangeably with secular associations). Over time, however, Americans began to join and belong less to such organizations (Putnam 2000). Much research has gone into explaining this phenomenon as well as the rationale for why many join organizations (Putnam 2000; Verba et al. 1995).

Scholars have also examined the effects of voluntary associations on policy responsiveness. The conventional wisdom is that citizens who participate in voluntary associations have their concerns addressed by government more so than those who do not participate in voluntary associations. If some Americans participate in voluntary associations less than others, a pluralist

Randall D. Swain is Associate Professor of Government at Eastern Kentucky University, Richmond, Kentucky. Maruice Mangum is Associate Professor of Political Science at Texas Southern University, Houston, Texas.

The American Review of Politics, Vol. 33, Fall, 2012: 189-210

(C)2012 The American Review of Politics 
perspective of American politics and society suggests that these individuals will not be as well-represented by government as those who are more involved in voluntary associations (Dahl 1982). An important test of these ideas is to examine the effects of involvement in voluntary associations on the political participation of Americans, specifically Black Americans, who, historically have not been well-represented by government descriptively or substantively. Therefore, this analysis examines the effects of voluntary associations - specifically the impact of affiliation with churches of varying stages of politicization and membership in secular associations-on the political participation of Black Americans.

Black Americans' involvement in secular associations, as well as religious associations, has declined in tandem with the decline in voluntary association by the wider American public since the 1960s (Putnam 2000). At the height of the Civil Rights Movement, Black Americans were very involved in voluntary associations such as the National Association for the Advancement of Colored People (NAACP), the Southern Christian Leadership Conference (SCLC), the Congress of Racial Equality (CORE), the Student Non-Violent Coordinating Committee (SNCC), and the National Urban League (Brown 1979). Brown (1979) found that in the mid-1970s, involvement in voluntary associations among Black Americans experienced a stark decline and faced challenges from an increasing number of new Black voluntary associations over differences in goals and vision. Brown (1979) argues further that the reasons for the loss in vitality of voluntary associations among Black Americans include the inability to remain relevant amidst a changing environment, leadership battles, declining support, and changes in membership eligibility.

Despite a decline in participating at the national level in voluntary associations, Black Americans have been rather active at the local level (Brown 1979). In fact, numerous voluntary associations have been created to recognize and help achieve African American goals and interests (Walton and Smith 2012). Moreover, from a voluntary organizational framework, the church is still a viable institution in facilitating the achievement of desirable policy outcomes in the African-American community. A proper examination of the effects of voluntary participation on the political participation of Black Americans should examine the issue by addressing both the church and non-religious voluntary associations.

Based on previous research, we know that the effects of both church and non-religious voluntary organizations on political participation are positive in regards to electoral behavior (Djupe and Gilbert 2006; Rosenstone and Hansen 2003; Verba and Nie 1972). Nevertheless, we assert that while both facilitate political participation, they do so differently. The implicit assumption in the voluntary association literature is that the effects of 
voluntary associations are the same in terms of their explanatory power. We contend that they are not, and propose a theory to explain why voluntary associations do not equally affect the political participation of Black Americans. Specifically, we theorize that the impact of religious and secular associations on political participation among Black Americans will depend on two very important factors - the degree of intensity required for a particular political activity and whether the political activity is electoral or nonelectoral in nature. In other words, we contend that the impact of churches and secular organizations as institutional frameworks for political activism among Black Americans are conditional in their effects. We expect secular associations to be related to political behavior that requires a greater degree of commitment and intensity. Thus, from a voluntary associational perspective, churches and secular associations should differ in the importance they place on political activities. The social climate in churches in the Black community will be more inclined to mobilize low-intensity forms of political participation while the climate in secular associations should foster highintensity forms of political activism.

\section{Literature Review}

Voluntary associations facilitate political participation by reducing the costs of participation, easing the burden of acquiring information, lowering personal financial costs, and providing an environment that fosters political activism (Djupe and Gilbert 2006; Rosenstone and Hansen 2003). Tate (1993) found that membership in voluntary associations is a correlate of voter turnout among Black Americans.

For African Americans, church affiliation constitutes the majority of their voluntary associations (Wald et al. 1988). Scholars have presented works indicating that the church is an effective agent in encouraging political participation among Black Americans (Brown and Wolford 1994; Calhoun-Brown 1996; Harris 1999; Morris 1984; Tate 1993). Additionally, civic and community organizations that traditionally have served the Black-American community, such as the NAACP and the Urban League, are known to facilitate political participation among Black Americans (McAdams 1982; Rosenstone and Hansen 2003; Tate 1993; Timpone 1995; Verba et al. 1995).

The literature suggesting that the church is a mobilizing force for Black Americans is abundant (Alex-Assensoh and Assensoh 2001; Brown and Wolford 1994; Calhoun-Brown 1996; Dawson, Brown, and Allen 1990; Harris 1994; Harris 1999; Tate 1993). Tate (1993) and Calhoun-Brown (1996) note that political churches (churches in which the process of politicization occurs) have positive effects on political participation. Political 
churches facilitate political knowledge (Tate 1993) and create a climate where political participation is expected (Calhoun-Brown 1996). CalhounBrown further describes political churches as being led by ministers who are politically active and who mobilize parishioners to engage in various forms of political participation.

Brown and Wolford (1994) demonstrate that the social setting of Black churches promotes political participation. Specifically, they point out that political churches overcome resource deficits among Black Americans with minimal socioeconomic resources. Similarly, Harris (1999) argues that Black churches foster civic and psychological resources that produce political participation. In his work on the 1984 presidential elections, Morris (1984) found that the church was a hub of organizational activity in the 1950s and 1960s and illustrated how it mobilized Black Americans to participate in politics during the Civil Rights Movement.

Nevertheless, societal changes since passage of the two land mark civil rights legislation in 1964 and 1965 have seen black religious institutions influencing social and political activism in more recent years that raises questions about the church's efficacy in facilitating social and political activism among Black Americans today (Calhoun-Brown 1999; McKenzie 2008). Calhoun-Brown argues (1999), for example, that affiliation with the Baptist church among African-Americans is more likely to predict conventional political activism than blacks affiliated with white religious institutions. Yet in a separate study, she finds that African-American religious affiliations that strongly emphasize otherworldly spiritual alternatives - the end of the world, heaven and the afterlife, etc.- - result in a decline in social activism and civic engagement in the black community among African Americans (Calhoun-Brown 1998). McKenzie (2008) finds that black churches today are not as effective as African American social and political organizations in promoting political activism.

Scholars have also sought to explain the link between membership in non-religious (secular) voluntary associations and political activism. Research has shown that secular voluntary associations enhance democratic norms and values (Olsen 1972; Stolle 1998; Verba et al. 1995). Community and civic organizations also provide members with opportunities to engage in activities which have spillover effects into politics (Verba et al. 1995). Because these skills are applicable in the political realm, participation in these organizations often leads to political participation. Thus, skills learned and developed in voluntary community organizations can easily be applied to political activism.

However, in general, these works focus solely on voting or, occasionally, on other forms of electoral behavior. Little is known about the types of political activities voluntary associations affect beyond voting. Missing from 
the literature on Black Americans are analyses that examine the effects of voluntary associations on other forms of electoral behavior besides voting and on non-electoral political participation. In this investigation, we seek to determine whether church and organizational membership encourage both types of political participation as well as specific electoral and non-electoral activities.

A second focus of this research, which we feel make the most important contribution to the political science literature, is to advance different expectations of religious associations and secular associations. While we expect both types of voluntary associations to have positive influences on political participation in general, we do not expect them to be equal in terms of their magnitude or significance. Our hypothesis is that religious associations have greater influence than secular associations on political behavior requiring less commitment and resources. Conversely, we anticipate that secular associations will be more influential than religious associations in encouraging political behavior that requires more commitment and resources. Thus, we propose that the effects of voluntary associations on the political participation of Black Americans are conditional, based on the level of commitment and resources required to perform the political activity.

\section{Modeling Political Participation}

Undergirding our argument is the contention that religious associations are more effective than secular associations in facilitating some political activities while secular associations are more efficacious than religious associations in influencing other forms of political activities. Since political activism varies in terms of commitment, effort, and resources required, we posit that religious associations and secular associations differ in the political activity they foster. Differences between religious and secular associations can be explained by differences in the degree of voluntarism and motivations to join.

While spiritual conviction is a factor in church attendance among Black Americans, church attendance and religious affiliation among Black Americans can also be explained by cultural and social norms within the Black community. We do not doubt that many Black Americans attend church because of spiritual devotion and strongly-held convictions, but it is also true that some continue to attend church because of habit, tradition, or pressure imposed by family and friends. Research on communal norms in the BlackAmerican community acknowledges the subtle social pressures brought to bear on Black Americans to attend church, even if on an infrequent basis (Ellison and Sherkat 1995; Hunt and Hunt 2000; Nelsen et al. 1971). Ellison and Sherkat's (1995) assertion that black churches function in many cases as 
"semi-involuntary" institutions substantiates the well known fact that religious involvement among many African Americans can just as readily be explained by familial and social expectations and the desire to avoid reproach, as it can, by denominational devotion and spiritual fervor.

Those in the Black community who attend church and participate in religious activities because of the social and familial expectations referred to by Ellison and Sherkat (1995), may nonetheless, still be led to become involved in some form of political activism. However, when church attendance and religious involvement is motivated more by superficial considerations (such as familial expectations) than by spiritual, we should expect that the nature of social and political activism performed by these individuals under the auspices of the church will be cursory in nature, requiring minimum commitment and effort. We refer to these individuals as truth believers and recognize that their social and political activism may be derived from a religious attendance and affiliation that was motivated by superficial considerations. ${ }^{1}$ That they are church affiliates cannot be disputed but the reasons for their religious affiliations cannot always be definitively ascertained and this compels us to question the intensity of their commitment to any subsequent political activism that may result. We are less likely, however, to question the commitment to social and political activism by individuals who belong to African American secular organizations and refer to them as true believers. We believe that the true believer's involvement in secular associations is mostly void of the superficial social sanction calculations that affect the thought processes of those we refer to as truth believers. True believers, are true believers, because their affiliation with community organizations and civil rights organizations can be more consistently explained by a deeper commitment to the goals and mission of the organization; they truly believe in the objectives and mission of these organizations and the ultimate goal these organizations have in common - the uplift of the black community.

Our view of the differences in considerations that lead to affiliation with religious institutions versus those that lead to involvement with secular voluntary associations are supported by Pollock (1982) who distinguishes between solidary and purposive organizations and Leighley (1996) who contends that member incentive and motivation are ultimately the most important determinants of how successful an organization's leadership will be in mobilizing members for social and political activism. Solidary organizations reinforce democratic norms and influence low-intensity forms of political activism such as voting, but not much else. However, those joining purposive, secular associations such as the NAACP typically have tangible, visible benefits in mind and are willing to undertake political activities advocated by these organizations. 
According to Pollock (1982), people purposely seek out organizations and community or grassroots organizations with the expectation of being mobilized for political and social activism. The same cannot be said of churches, however, in that any political mobilization that occurs through their auspices occurs as an unintended result of membership and affiliation (Leighley 1996).

Indeed, we differentiate between political and non-political churches, but do so with the understanding that the difference stems from clergymen who lead Black churches, not from the laity who may join a political church. In the former, recruitment, mobilization, and activity are intentional. In the latter, congregants are recruited and mobilized for social and political activism because the minister created an environment that fostered and encouraged a spiritual worldview that included social justice and equality. Therefore, secular associations should be more successful than religious voluntary associations at encouraging members to engage in high-intensity political activities that require more commitment, effort, and resources.

\section{Data and Measures}

Data for this study comes from the 1996 National Black Election Study (NBES). The NBES is a national telephone survey of voting-aged Black Americans that queries respondents about political behavior and attitudes. Prior to the presidential election in 1996, 1,216 Black Americans were contacted and interviewed, and 854 were contacted for a follow-up interview after the presidential election. The sample was collected through the use of a stratified sampling technique.

While the data are more than a decade old, it is still the best source of data for political research undertakings on Black Americans. It has a large enough sample of Black Americans to conduct analyses involving a number of pertinent variables. Furthermore, it surpasses other data sets by possessing question items that capture the effects of the concepts we wish to measure. No other data set asks the questions we need: questions that capture the impact of the church's context or environment as well as membership in secular organizations (particularly organizations that traditionally address the needs and concerns of Black Americans). We provide a detailed description and coding scheme for each variable in this analysis in the Appendix.

\section{Dependent Variables}

In seeking to assess the level of electoral and non-electoral activism among Black Americans and the factors that encourage these modes of activism, we follow the literature by creating two indexes. These are two 
additive indexes, one that represents electoral behavior (Cronbach alpha $=$ .599 ) and another to denote non-electoral behavior (Cronbach alpha $=.656$ ).

For verification, a factor analysis was performed, and the variables loaded onto two dimensions (see Table 1). These two dimensions yielded an electoral dimension and a non-electoral dimension, reinforcing the appropriateness of the indexes. There are seven response points for the electoral index (Voting, Talk to People, Voter Registration, Raise Money, Campaign for a Black Candidate, and Contact Government), ranging from zero to six and five response points for the non-electoral index (Political Meetings/ Rallies, Signed Petition, Protest/Demonstration, and Picketed/Sit-In/Boy$c o t t$ ), ranging from zero to four.

We employ ordinary least squares regression as the method of analysis to assess the impact of the independent variables on the electoral and nonelectoral indexes of political participation. In addition to the two indexes, we estimate each of the individual kinds of behavior that make up the electoral and non-electoral indexes. That is, we create a series of logistic regression analyses to estimate each electoral mode of participation and each nonelectoral mode of participation.

\section{Key Independent Variables}

The impact of church on Black Americans' political behavior is measured by four variables. Frequency of church attendance (Church Attendance) is measured on a six-point scale (zero indicating never attends church and six indicating the highest level of church attendance - two or more times a week). Political Church, the second variable, is defined and operationalized by Tate (1993) and Calhoun-Brown (1996) as political churches where congregants discuss politics or where congregants overhear discussion or announcements of the presidential elections. Political churches provide a setting where congregants can hear messages about electoral campaigns, the candidates, and issues and be given the opportunity to contribute financially to a campaign. The variable Political Church is measured by combining two questions to create a three-point variable. The first question asks respondents if their church made any announcements pertaining to the 1996 presidential election campaign. The second question asks if respondents' churches encouraged voting in the election. Responses indicating that both experiences occurred at the church or place of worship were coded 2, responses indicating only one of the two occurred were coded 1, and responses indicating neither occurred were coded 0 .

The third variable, Endorsing Church, is a church or place of worship that endorsed a candidate in the November 1996 presidential election. This variable indicates a level of political discourse at one's church or place of 


\section{Table 1. Factor Analysis of Electoral and Non-Electoral Political Participation Variables}

\begin{tabular}{lcc}
\hline & $\begin{array}{c}\text { Electoral } \\
\text { Dimension }\end{array}$ & $\begin{array}{c}\text { Non-Electoral } \\
\text { Dimension }\end{array}$ \\
\hline Campaign for a Black Candidate & .756 & \\
Raise Money & .727 & \\
Political Meetings or Rallies & .619 & \\
Voter Registration & .478 & .701 \\
Talk to People & .448 & .682 \\
Voting & .271 & .652 \\
Contact Government & & .648 \\
Signed Petition & & \\
Protest/ Demonstration & & \\
Picketed/Sit-In/Boycott & & \\
Source: 1996 National Black Election Study. & & \\
\hline
\end{tabular}

worship that is more distinctive and direct when compared to the political church variable. Previous research has delineated church types beyond a politicized and non-politicized dyad (Mangum 2008), and shows that political churches and endorsing churches operate on different dimensions in how they orient congregants towards political activism.

Otherworldly-Thisworldly Orientation indicates the preference of involvement of one's church or place of worship in political affairs. If the respondent wants his or her church or place of worship involved in political affairs, then he or she will be likely to participate in both electoral and nonelectoral political participation. If the respondent does not want his or her church or place of worship involved in political affairs, then his or her political participation would not be affected. These items capture not only the salience and presence of the church in the Black-American community, but also reflect religious commitment and the contextual dynamics we believe inform the church's effects on political participation.

Additional variables were considered but, ultimately, were omitted from the final analyses. First, we created interaction terms that yielded Attendance x Political Church, Attendance x Endorsing Church, and Attendance $x$ Otherwordly-Thisworldly Orientation with the understanding that the more one attends these types of churches/places of worship, the more one will participate in politics. We discovered that regardless of whether we include or omit these variables, our findings do not change. In fact, the basic argument would be that we expect more of the same, so we avoid this redundancy. Therefore, given that nothing is lost or gained by their inclusion, we 
omitted these variables from the models. Secondly, we believe that Political Church and Endorsing Church should not be combined. One reason is that we follow the literature in operationalizing a political church. Another reason for maintaining separation is that the Political Church question was asked in the pre-election wave in 1996 and the Endorsing Church question was asked in the post-election wave in 1996. Lastly, the settings of the two kinds of churches are qualitatively different. The Political Church stops short of endorsing a candidate, which is a violation of IRS regulations, but an Endorsing Church is willing to violate the law to endorse a candidate. While both are expected to facilitate political participation, an Endorsing Church might have more impact because its setting may be considered more extreme in its approach to mobilizing its congregants.

Two separate dichotomous organizational measures are employed for secular associations (membership in organizations). The first variable, Black Organization, assesses the effects of membership in an organization that deals more specifically with issues important to Black Americans and is measured by asking respondents if they belonged to an organization that seeks to improve the condition of Black Americans. The second variable, Community Organization, assesses membership in a community-based organization and is measured by asking whether respondents worked with others to address a community problem within the previous twelve months. We hypothesize that membership in an organization with a Black-American focus and membership in a community-based organization both lead to greater electoral and non-electoral participation.

\section{Control Variables}

Education is measured with a nine-point scale, ranging from those with a grade school education (coded 1) to those who have a doctorate or law degree (coded 9). The mean education level is some college education, but not having obtained a bachelor's degree. Income is measured with an 11point scale, ranging from $\$ 1-\$ 10,000$ to over $\$ 105,000$. The mean income range is $\$ 25,000-\$ 35,000$. Age is the respondent's age and the mean age is approximately 40 years old. Gender is coded 1 for male, 0 for female, with a mean of .34, suggesting more females make up this sample than males.

\section{Findings and Discussion}

Table 2 reports the results of the multiple regression analyses for the electoral and non-electoral political participation indexes. Table 3 presents the results of each of the individual electoral political participation variables. Table 4 provides the results of the individual non-electoral political partici- 
pation variables. The results in these tables lend credibility to our central premise that while religious associations and secular associations promote electoral as well as non-electoral modes of political participation, there are subtle differences in the types of activities they promote.

Table 2 shows how important both religious and secular associations are in facilitating electoral and non-electoral modes of political activism.

\section{Table 2. Church and Organizational Influences on Electoral and Non-Electoral Political Participation Indexes among Black Americans}

\begin{tabular}{|c|c|c|}
\hline Independent Variables $^{\mathrm{a}}$ & $\begin{array}{l}\text { Electoral } \\
\text { Index }\end{array}$ & $\begin{array}{l}\text { Non-Electoral } \\
\text { Index }\end{array}$ \\
\hline Black Organization & $\begin{array}{l}.366^{* *} \\
(.117)\end{array}$ & $\begin{array}{l}.433 * * * \\
(.099)\end{array}$ \\
\hline Community Organization & $\begin{array}{l}.513 * * * \\
(.110)\end{array}$ & $\begin{array}{l}.470 * * * \\
(.093)\end{array}$ \\
\hline Church Attendance & $\begin{array}{l}.035 \\
(.035)\end{array}$ & $\begin{array}{l}.062 * \\
(.029)\end{array}$ \\
\hline Political Church & $\begin{array}{l}.151^{*} \\
(.068)\end{array}$ & $\begin{array}{l}.166^{* *} \\
(.057)\end{array}$ \\
\hline Endorsing Church & $\begin{array}{l}.466 * * * \\
(.126)\end{array}$ & $\begin{array}{l}.329 * * \\
(.105)\end{array}$ \\
\hline Otherworldly-Thisworldly Orientation & $\begin{array}{l}-.008 \\
(.026)\end{array}$ & $\begin{array}{l}.013 \\
(.022)\end{array}$ \\
\hline Education & $\begin{array}{c}.083 * \\
(.033)\end{array}$ & $\begin{array}{l}.112^{* * * *} \\
(.028)\end{array}$ \\
\hline Income & $\begin{array}{l}-.011 \\
(.021)\end{array}$ & $\begin{array}{l}.068 * * * \\
(.018)\end{array}$ \\
\hline Age & $\begin{array}{l}.009 * * \\
(.003)\end{array}$ & $\begin{array}{l}.001 \\
(.003)\end{array}$ \\
\hline Gender & $\begin{array}{l}-.120 \\
(.104)\end{array}$ & $\begin{array}{c}.015 \\
(.087)\end{array}$ \\
\hline Constant & $\begin{array}{l}.458 \\
(.273)\end{array}$ & $\begin{array}{l}-.427 \\
(.229)\end{array}$ \\
\hline $\mathrm{N}$ & 650 & 645 \\
\hline Df & 10 & 10 \\
\hline Adjusted $\mathrm{R}^{2}$ & .17 & .26 \\
\hline
\end{tabular}


Membership in an organization that has a Black focus (Black Organization), membership in a community organization (Community Organization), attending a political church (Political Church), and church endorsement of political candidates (Endorsing Church) are all positively related to both the Electoral and Non-Electoral Political Participation Indexes. Interestingly, when it comes to predicting involvement in electoral and non-electoral political activism, Endorsing Church shows a much stronger measure of association than Political Church and the coefficients for Endorsing Church are more robust than those for Political Church.

The coefficient for Black Organization shows a stronger effect on nonelectoral activism than it does for electoral activism $(b=.433$ and $b=.366$ for non-electoral and electoral activism, respectively), in terms of the coefficient as well as the strength of association. The same can be said for Political Church $(b=.166$ and $b=.151$ for non-electoral and electoral activism, respectively). The opposite is the case for Community Organization ( $b=$ .513 for electoral activism, compared to $b=.470$ for non-electoral activism) and Endorsing Church $(b=.466$ for electoral activism, compared to $b=.329$ for non-electoral activism). Interestingly, Church Attendance is not significant in the Electoral Index, but is in the Non-Electoral Index.

More relevant to our claims, the data in Tables 3 and 4 suggest that religious associations are more influential than secular associations when it comes to facilitating political participation low in intensity, requiring less effort and resources, but the opposite is the case when it comes to fostering participation high in intensity requiring more effort and resources. Table 3 shows the logistic regression results of each of the individual electoral activities. The first model presented in Column 1 shows the independent variables' effects on Voting. Political Church is the only variable of interest that approaches statistical significance $(\mathrm{b}=.520)$. Black Americans who attend a political church are more likely to vote than Black Americans who do not attend a political church. In Column 2, both Church Attendance and Endorsing Church show a significant association with Talking to People. Black Americans who attend church with more frequency and Black Americans who attend a church that endorses candidates are more likely to talk to people about their preferred candidate or party.

Column 3 of Table 3 shows the results of the logistic regression analysis for the Political Meetings/Rallies model. Endorsing Church, Black Organization, and Community Organization reach statistical significance. Voter Registration (Column 4), Raise Money (Column 5), and Campaign for a Black Candidate (Column 6) are all influenced by Community Organization. The trend that stands out most conspicuously in Table 3 is that the measures of secular voluntary associations are statistically significant with the most intensive forms of electoral political activism. Both Black Organization 
Table 3. Church and Organizational Influences on Electoral Political Participation Indicators among Black Americans

\begin{tabular}{|c|c|c|c|c|c|c|}
\hline $\begin{array}{l}\text { Dependent } \\
\text { Variables }\end{array}$ & Voting & $\begin{array}{l}\text { Talk to } \\
\text { People }\end{array}$ & $\begin{array}{l}\text { Political } \\
\text { Meetings } \\
\text { or Rallies }\end{array}$ & $\begin{array}{l}\text { Voter } \\
\text { Regist }\end{array}$ & $\begin{array}{l}\text { Raise } \\
\text { Money }\end{array}$ & $\begin{array}{c}\text { Campaign } \\
\text { for a } \\
\text { Black } \\
\text { Candidate }\end{array}$ \\
\hline \multicolumn{7}{|c|}{ Independent Variables ${ }^{\mathrm{a}}$} \\
\hline $\begin{array}{l}\text { Black } \\
\text { Organization }\end{array}$ & $\begin{array}{l}.147 \\
(.263)\end{array}$ & $\begin{array}{l}.157 \\
(.197)\end{array}$ & $\begin{array}{l}.692^{*} \\
(.271)\end{array}$ & $\begin{array}{l}.368 \\
(.237)\end{array}$ & $\begin{array}{l}.345 \\
(.301)\end{array}$ & $\begin{array}{l}1.153^{* * *} \\
(.304)\end{array}$ \\
\hline $\begin{array}{l}\text { Community } \\
\text { Organization }\end{array}$ & $\begin{array}{l}.327 \\
(.236)\end{array}$ & $\begin{array}{l}.340 \\
(.186)\end{array}$ & $\begin{array}{l}1.075 * * * \\
(.280)\end{array}$ & $\begin{array}{l}.693^{* *} \\
(.234)\end{array}$ & $\begin{array}{l}1.055^{* *} \\
(.320)\end{array}$ & $\begin{array}{l}.985^{* *} \\
(.318)\end{array}$ \\
\hline $\begin{array}{l}\text { Church } \\
\text { Attendance }\end{array}$ & $\begin{array}{l}-.016 \\
(.070)\end{array}$ & $\begin{array}{l}.130^{*} \\
(.060)\end{array}$ & $\begin{array}{l}-.003 \\
(.090)\end{array}$ & $\begin{array}{l}.060 \\
(.076)\end{array}$ & $\begin{array}{l}.095 \\
(.103)\end{array}$ & $\begin{array}{l}-.058 \\
(.105)\end{array}$ \\
\hline $\begin{array}{l}\text { Political } \\
\text { Church }\end{array}$ & $\begin{array}{l}.520 * * * \\
(.141)\end{array}$ & $\begin{array}{l}.024 \\
(.117)\end{array}$ & $\begin{array}{l}.156 \\
(.176)\end{array}$ & $\begin{array}{l}.204 \\
(.150)\end{array}$ & $\begin{array}{l}.259 \\
(.203)\end{array}$ & $\begin{array}{l}.046 \\
(.197)\end{array}$ \\
\hline $\begin{array}{l}\text { Endorsing } \\
\text { Church }\end{array}$ & $\begin{array}{l}-.110 \\
(.289)\end{array}$ & $\begin{array}{l}.638 * * \\
(.208)\end{array}$ & $\begin{array}{l}.883 * * \\
(.269)\end{array}$ & $\begin{array}{l}.116 \\
(.252)\end{array}$ & $\begin{array}{c}.463 \\
(.301)\end{array}$ & $\begin{array}{l}1.052 * * * \\
(.294)\end{array}$ \\
\hline $\begin{array}{l}\text { Otherworldly- } \\
\text { Thisworldly } \\
\text { Orientation }\end{array}$ & $\begin{array}{l}-.010 \\
(.055)\end{array}$ & $\begin{array}{l}-.049 \\
(.045)\end{array}$ & $\begin{array}{c}.019 \\
(.065)\end{array}$ & $\begin{array}{l}-.003 \\
(.056)\end{array}$ & $\begin{array}{l}-.025 \\
(.073)\end{array}$ & $\begin{array}{c}.041 \\
(.072)\end{array}$ \\
\hline Education & $\begin{array}{l}.293 * * * \\
(.080)\end{array}$ & $\begin{array}{l}.072 \\
(.055)\end{array}$ & $\begin{array}{l}-.031 \\
(.078)\end{array}$ & $\begin{array}{l}.143^{*} \\
(.067)\end{array}$ & $\begin{array}{l}.143 \\
(.010)\end{array}$ & $\begin{array}{l}-.039 \\
(.085)\end{array}$ \\
\hline Income & $\begin{array}{l}.023 \\
(.044)\end{array}$ & $\begin{array}{l}-.010 \\
(.036)\end{array}$ & $\begin{array}{l}-.070 \\
(.052)\end{array}$ & $\begin{array}{l}-.015 \\
(.046)\end{array}$ & $\begin{array}{l}.065 \\
(.060)\end{array}$ & $\begin{array}{l}-.053 \\
(.058)\end{array}$ \\
\hline Age & $\begin{array}{l}.035^{* * *} \\
(.008)\end{array}$ & $\begin{array}{c}.001 \\
(.006)\end{array}$ & $\begin{array}{l}-.002 \\
(.008)\end{array}$ & $\begin{array}{l}-.004 \\
(.008)\end{array}$ & $\begin{array}{l}.043 * * * \\
(.010)\end{array}$ & $\begin{array}{c}.006 \\
(.009)\end{array}$ \\
\hline Gender & $\begin{array}{l}.331 \\
(.213)\end{array}$ & $\begin{array}{l}-.236 \\
(.176)\end{array}$ & $\begin{array}{l}-.489 \\
(.251)\end{array}$ & $\begin{array}{l}-.075 \\
(.222)\end{array}$ & $\begin{array}{l}-.385 \\
(.285)\end{array}$ & $\begin{array}{l}-.209 \\
(.279)\end{array}$ \\
\hline Constant & $\begin{array}{c}-2.17 * * * \\
(.578)\end{array}$ & $\begin{array}{c}-1.164^{*} \\
(.467)\end{array}$ & $\begin{array}{c}-2.343^{* *} \\
(.682)\end{array}$ & $\begin{array}{c}-2.715^{* * *} \\
(.598)\end{array}$ & $\begin{array}{c}-6.16^{* * *} \\
(.878)\end{array}$ & $\begin{array}{c}-3.198 * * * \\
(.774)\end{array}$ \\
\hline $\mathrm{N}$ & 662 & 662 & 662 & 662 & 661 & 662 \\
\hline Df & 10 & 10 & 10 & 10 & 10 & 10 \\
\hline $\begin{array}{l}-2 \log \\
\text { Likelihood }\end{array}$ & 616.959 & 849.363 & 468.785 & 593.873 & 380.553 & 393.148 \\
\hline Pseudo $\mathrm{R}^{2}$ & .19 & .07 & .17 & .09 & .21 & .20 \\
\hline \multicolumn{7}{|c|}{$\begin{array}{l}\text { Source: } 1996 \text { National Black Election Study. } \\
{ }^{*} \mathrm{p}<.05 ; * * \mathrm{p}<.01 ; * * * \mathrm{p}<.001 \\
{ }^{\mathrm{a} B e t a s} \text { are unstandardized coefficients. }\end{array}$} \\
\hline
\end{tabular}


and Community Organization show statistical significance with Political Meetings and Rallies $(b=.692, p<.05$ and $b=1.075, p<.001$, respectively), and Campaign for a Black Candidate $(b=1.153, p<.001$ and $b=.985$, $\mathrm{p}<.01$, respectively), while Community Organization shows statistical significance with voter registration $(b=.693, p<.01)$ and raising money for political candidates $(\mathrm{b}=1.055, \mathrm{p}<.01)$.

The measures for Black churches' influence in facilitating electoral political activism are evident in influencing Voting and Talking to People. Church Attendance approaches statistical significance with Talking to People $(b=.130, p<.05)$, Political Church is statistically significant with Voting $(b=.520, p<.001)$, while Endorsing Church suggests the strongest facilitator of electoral political activism, approaching statistical significance with Talking to People $(\mathrm{b}=.638, \mathrm{p}<.01)$, Attendance at Political Meetings and Rallies $(\mathrm{b}=.883, \mathrm{p}<.01)$, and Campaigning for a Black Candidate $(\mathrm{b}=$ $1.052, \mathrm{p}<.001)$. Given the degree of support for particular political candidates, we are not surprised that an Endorsing Church would be so effective in facilitating a broad spectrum of electoral political activities.

Table 4 shows the logistic regression results of each of the individual non-electoral activities. The data suggest that both religious and secular associations facilitate non-electoral political activism that is relatively low intensity in nature. Both Black Organization and Community Organization are related to Contacting a Public Official or Public Agency $(b=.680$, $\mathrm{p}<.01$ and $\mathrm{b}=.683, \mathrm{p}<.001$, respectively) as is Political Church $(\mathrm{b}=.349$, $\mathrm{p}<.01)$. Community Organization, Church Attendance, and Political Church are related to Signing a Petition $(b=.737, p<.001 ; b=.134$, $\mathrm{p}<.05$; and $\mathrm{b}=.307, \mathrm{p}<.05$, respectively). Thus, when it comes to facilitating relatively low intensity forms of non-electoral political activism, Black churches and secular voluntary associations facilitate political activism among adherents and members.

The opposite occurs when the focus is on more intense forms of nonelectoral political activism. Black Organization and Community Organization are significant with Attending a Protest or Demonstration $(b=.858$, $\mathrm{p}<.001$ and $\mathrm{b}=1.073, \mathrm{p}<.001$, respectively) as is Endorsing Church $(\mathrm{b}=$ $.586, \mathrm{p}<.05)$; the Endorsing Church's measure of association is weaker than that of Black Organization and Community Organization. Black Organization is statistically significant with Participating in a Picket, Sit-in or Boycott $(\mathrm{b}=.803, \mathrm{p}<.01)$ and so is Endorsing Church $(\mathrm{b}=.624, \mathrm{p}<.05)$, but, as with Attending a Protest or Demonstration, the measures of association for Endorsing Church are less than that of the measures of Black Organization. The pattern of the findings in Table 4, like the pattern of findings in Table 3, lends strong support for our claim that secular voluntary associations are more efficacious when it comes to facilitating the most intense form of nonelectoral political activism than religious voluntary associations. 
Table 4. Church and Organizational Influences on Non-Electoral Political Participation Indicators among Black Americans

\begin{tabular}{|c|c|c|c|c|}
\hline $\begin{array}{l}\text { Dependent } \\
\text { Variables }\end{array}$ & $\begin{array}{c}\text { Contact } \\
\text { Government }\end{array}$ & $\begin{array}{l}\text { Signed } \\
\text { Petition }\end{array}$ & $\begin{array}{c}\text { Protest/ } \\
\text { Demonstration }\end{array}$ & $\begin{array}{c}\text { Picketed/Sit-In/ } \\
\text { Boycott }\end{array}$ \\
\hline \multicolumn{5}{|c|}{ Independent Variables ${ }^{\mathrm{a}}$} \\
\hline $\begin{array}{l}\text { Black } \\
\text { Organization }\end{array}$ & $\begin{array}{l}.680 * * \\
(.203)\end{array}$ & $\begin{array}{l}.368 \\
(.207)\end{array}$ & $\begin{array}{l}.858 * * * \\
(.242)\end{array}$ & $\begin{array}{l}.800 * * \\
(.306)\end{array}$ \\
\hline $\begin{array}{l}\text { Community } \\
\text { Organization }\end{array}$ & $\begin{array}{l}.683 * * * \\
(.195)\end{array}$ & $\begin{array}{l}.737 * * * \\
(.192)\end{array}$ & $\begin{array}{l}1.073 * * * \\
(.249)\end{array}$ & $\begin{array}{l}.242 \\
(.304)\end{array}$ \\
\hline $\begin{array}{l}\text { Church } \\
\text { Attendance }\end{array}$ & $\begin{array}{l}-.010 \\
(.066)\end{array}$ & $\begin{array}{l}.134^{*} \\
(.062)\end{array}$ & $\begin{array}{l}.152 \\
(.080)\end{array}$ & $\begin{array}{l}.201^{*} \\
(.097)\end{array}$ \\
\hline $\begin{array}{l}\text { Political } \\
\text { Church }\end{array}$ & $\begin{array}{l}.349 * * \\
(.128)\end{array}$ & $\begin{array}{l}.307^{*} \\
(.120)\end{array}$ & $\begin{array}{l}.150 \\
(.160)\end{array}$ & $\begin{array}{l}.307 \\
(.200)\end{array}$ \\
\hline $\begin{array}{l}\text { Endorsing } \\
\text { Church }\end{array}$ & $\begin{array}{l}.423 \\
(.224)\end{array}$ & $\begin{array}{l}.349 \\
(.229)\end{array}$ & $\begin{array}{l}.586^{*} \\
(.252)\end{array}$ & $\begin{array}{l}.624^{*} \\
(.307)\end{array}$ \\
\hline $\begin{array}{l}\text { Otherworldly- } \\
\text { Thisworldly } \\
\text { Orientation }\end{array}$ & $\begin{array}{l}.059 \\
(.049)\end{array}$ & $\begin{array}{l}.044 \\
(.047)\end{array}$ & $\begin{array}{l}-.069 \\
(.059)\end{array}$ & $\begin{array}{l}.044 \\
(.073)\end{array}$ \\
\hline Education & $\begin{array}{l}.207 * * \\
(.060)\end{array}$ & $\begin{array}{l}.237 * * \\
(.061)\end{array}$ & $\begin{array}{l}.096 \\
(.069)\end{array}$ & $\begin{array}{l}.050 \\
(.087)\end{array}$ \\
\hline Income & $\begin{array}{l}.120 * * \\
(.039)\end{array}$ & $\begin{array}{l}.098 * * \\
(.037)\end{array}$ & $\begin{array}{l}.049 \\
(.048)\end{array}$ & $\begin{array}{l}.222 * * * \\
(.063)\end{array}$ \\
\hline Age & $\begin{array}{l}.015^{*} \\
(.006)\end{array}$ & $\begin{array}{l}.003 \\
(.006)\end{array}$ & $\begin{array}{l}-.003 \\
(.008)\end{array}$ & $\begin{array}{l}-.026^{*} \\
(.011)\end{array}$ \\
\hline Gender & $\begin{array}{l}.078 \\
(.194)\end{array}$ & $\begin{array}{l}.008 \\
(.184)\end{array}$ & $\begin{array}{l}-.393 \\
(.230)\end{array}$ & $\begin{array}{c}.256 \\
(.288)\end{array}$ \\
\hline Constant & $\begin{array}{l}-3.800 * * * \\
(.552)\end{array}$ & $\begin{array}{c}-2.72 * * * \\
(.507)\end{array}$ & $\begin{array}{l}-3.269 * * * \\
(.640)\end{array}$ & $\begin{array}{c}-4.43 * * * \\
(.814)\end{array}$ \\
\hline $\mathrm{N}$ & 661 & 659 & 661 & 661 \\
\hline Df & 10 & 10 & 10 & 10 \\
\hline $\begin{array}{l}-2 \log \\
\text { Likelihood }\end{array}$ & 741.191 & 796.994 & 536.163 & 388.570 \\
\hline Pseudo $\mathrm{R}^{2}$ & .26 & .21 & .23 & .17 \\
\hline \multicolumn{5}{|c|}{$\begin{array}{l}\text { Source: } 1996 \text { National Black Election Study. } \\
{ }^{*} \mathrm{p}<.05 ; * * \mathrm{p}<.01 ; * * * \mathrm{p}<.001 \\
{ }^{\mathrm{a} B e t a s} \text { are unstandardized coefficients. }\end{array}$} \\
\hline
\end{tabular}




\section{Discussion}

From the data presented here, we draw several conclusions about electoral and non-electoral political activism among Black Americans. First, non-electoral political activism remains a viable way for Black Americans to express their political concerns and public policy preferences in ways other than voting in elections. Although data that examined the level of nonelectoral involvement by Black Americans during the late 1960s and early 1970s are not used in this study, based on findings presented from that period, it seems that the display of non-electoral activism by Black Americans has not changed dramatically in the last three to four decades. That is, though Black Americans have gained more access to the ballot box, they still engage in activities reminiscent of the Civil Rights Movement. Working to achieve social, economic, and political ends, Black Americans are still motivated to go outside the political system.

Second, we find that both types of voluntary associations under investigation were positive influences on both electoral and non-electoral political participation. When significant, each of the different church and organizational variables were positively related to both electoral and non-electoral political participation. As hypothesized, religious and secular voluntary associations encourage Black political participation.

Third, unlike Tate (1993), we find that organizational memberships are more important facilitators of activism among Black Americans than the church. Organizational membership variables were significant more often than church variables, especially when it came to non-electoral forms of political participation. We attribute this to the general trend of churches being more than religious institutions. Many churches in Black communities offer services such as child care, banking, and other services that cater to their congregants' non-spiritual needs. The rise in the number of mega churches (very large) may also play a part. In order to attract and maintain parishioners, mega churches offer many services. Their appeal is more economic and social than purely religious. Additionally, and as hypothesized, endorsing churches had more impact on political participation of Black Americans than political churches.

Fourth, the results indicate that the kind of voluntary association varies with the form of participation Black Americans engage in themselves. Religious and secular voluntary associations vary in their effects on electoral and non-electoral political participation. Religious voluntary associations are more influential than secular voluntary associations when the political activity requires less commitment and fewer resources. Conversely, secular voluntary associations are more influential than religious voluntary associations when the political activity requires greater commitment and more 
resources. More intense activities require greater effort, commitment, and more civic skills. The voluntary association with the more voluntary aspect to it, the secular voluntary association, provides more natural motivation to Black Americans and calls for more skills that lead to greater participation in high-intensity political activities than do religious voluntary associations.

The consequences of some Americans being more active in politics and others less so have enormous effects on our democracy. If some citizens participate in voluntary associations more than others and that, in part, explains why some citizens involve themselves in politics more, then these individuals get more out of government. As a result, regardless of race, those who participate in politics reap more rewards and benefits than those who do not. However, the deleterious effects of non-participation are lessened when Black Americans develop social capital through participation at church and other voluntary associations. This participation enhances their abilities to gain a modicum of descriptive and substantive representation. Therefore, voluntary associations play an important role in providing representation. For those who traditionally participate less in politics, voluntary associations are even more important.

Future research should address more thoroughly the influence voluntary associations have on political participation in general and the political participation of Black Americans. There needs to be an examination of the types of skills and resources (organizational, psychological, material, etc.) that lead to differing, conditional effects on political participation by religious associations and secular associations. That is, what skills are developed or resources brought to bear by a religious association that is lacking in secular associations, and vice versa, that lead to participation in some activities but not other kinds of political activities?

While we do not anticipate that Black Americans have changed drastically in the last two to three decades (they still support liberal policies, identify themselves overwhelmingly as Democrats, and vote for Democratic candidates), it behooves political science to reexamine the link between voluntary associations and the participation of Black Americans. For instance, do voluntary associations have a greater impact on participation among Black Americans during election cycles more beneficial to the Republican Party? That is, do voluntary associations increase the likelihood of voting when participation otherwise would not be likely? Future research should examine the skills and resources as well as the political environment under which voluntary associations operate. 


\section{APPENDIX}

Following are the items from the 1996 NBES used to construct dependent and independent variables.

\section{Dependent Variables}

\section{ELECTORAL POLITICAL PARTICIPATION}

(1) Voting

"In talking to people about elections, we often find that a lot people were not able to vote because they weren't registered, they were sick, or they just didn't have time. How about you-did you vote in the elections this November?"

1 yes, voted

0 no, didn't vote

(2) Talk to People

"During the campaign, did you talk to any people and try to show them why they should vote for or against one of the parties or candidates?"

$$
1 \text { yes }
$$

0 no

(3) Voter Registration

"Did you help with a voter registration drive or help get people to the polls on Election Day?"

1 yes

0 no

(4) Raise Money

"Did you give any money to or help raise money for any of the candidates?"

1 yes

0 no

(5) Campaign for a Black Candidate

"During this election year, did you help campaign for a Black candidate?"

1 yes

0 no

(6) Political Meetings/Rallies

"During the campaign did you go to any political meetings, rallies, speeches, dinners, or things like that in support of a particular candidate?"

1 yes
0 no

\section{NON-ELECTORAL POLITICAL PARTICIPATION}

"Now, I'm going to read a list of things people have done to protest something they felt needed to be changed in the nation, their neighborhood, schools, or communities. Please tell if you have done any of the following in the last five years."

(7) Contact Government

Contacted a public official or agency?

1 yes

0 no

(8) Signed Petition

"Signed a petition in support of something or against something?"

1 yes

0 no 


\section{APPENDIX (continued)}

(9) Protest/Demonstration

"Attended a protest or demonstration?"

1 yes

0 no

(10) Picketed/Sit-In/Boycott

"Picketed, taken part in a sit-in, or boycotted a business or government agency"

1 yes

0 no

\section{Independent Variables}

\section{ORGANIZATIONAL MEMBERSHIP}

(1) Black Organization

"Are you a member of any organization working to improve the status of Black Americans?"

1 yes
0 no

(2) Community Organization

"In the last twelve months, have you worked with others or joined an organization in your community to do something about some community problem?"

1 yes
0 no

\section{CHURCH}

(3) Church Attendance

"Would you say you go to church or place of worship every week, almost every week, once or twice a month, a few times a year, or never?"

6 two or more times a week

5 every week

4 almost every week

3 once or twice a month

2 a few times a year

1 never

(4) Political Church

"Have you heard any announcements or talks about the presidential campaign in your church or place of worship so far this year?"

"Has your church or place of worship encouraged members to vote in this election?"

2 heard announcements about campaign in church and church encouraged members to vote

1 either heard announcements about campaign in church or church encouraged members to vote in the election

0 neither heard announcements about campaign in church, nor did church encourage members to vote

(5) Endorsing Church

"Did your church or place of worship endorse any candidates during this election year?"

1 yes

0 no 


\section{APPENDIX (continued)}

(6) Otherworldly-Thisworldly Orientation

"Do you think churches or places of worship should be involved in political matters?"

1 yes

0 no

\section{CONTROLS}

(7) Income

(8) Education

(9) Gender

Income Range \$0-105,000 (coded 1-11)

(10) Age

Grade School to Doctorate/Law Degree (coded 1-9)

Male $=1 ;$ Female $=0$

Age in years, ranging from $17-90$

\section{NOTES}

${ }^{1}$ It is common for church affiliates to believe and refer to their particular religious denomination as "the truth," which suggest their belief that their denomination's theological doctrines exclusively contain the requirements for spiritual salvation.

\section{REFERENCES}

Alex-Assensoh, Yvette, and A.B. Assensoh. 2001. Inner-City Contexts, Church Attendance, and African-American Political Participation. Journal of Politics 63(3):886901.

Brown, John A. 1979. The Present Lethargy of Black Voluntary Associations. Phylon 40(2):195-202.

Brown, Ronald, and Monica Wolford, M. 1994. Religious Resources and African-American Political Action. National Political Science Review 4:30-48.

Calhoun-Brown, Allison. 1996. African-American Churches and Political Mobilization: The Psychological Impact of Organizational Resources. Journal of Politics 58(4): 935-953.

Calhoun-Brown, Allison. 1998. While Marching to Zion: Otherworldliness and Racial Empowerment in the Black Community. Journal for the Scientific Study of Religion 37(3): 427-439.

Calhoun-Brown, Allison. 1999. The Imgage of God: Black Theology and Racial Empowerment in the African-American Community. Review of Religious Research 40(3):197-212.

Cone, James. H. 1989. Black Theology as Liberation Theology. In African American Religious Studies, ed. Gayraud Wilmore. Durham, NC: Duke University Press.

Dahl, Robert. 1982. Dilemmas of Pluralist Democracy. New Haven, CT: Yale University Press

Dawson, Michael, Ronald Brown, and Richard Allen. 1990. Racial Belief Systems, Religious Guidance, and African-American Political Participation. National Political Science Review 2:22-44. 
Djupe, Paul A., and Christopher Gilbert. 2006. The Resourceful Believer: Generating Civic Skills in Church. Journal of Politics 68(1):116-127.

Ellison, Christopher G., and Darren E. Sherkat. 1995. The 'Semi-involuntary Institution' Revisited: Regional Variations in Church Participation Among Black Americans. Social Forces 73(4):1415-1437.

Harris, Frederick C. 1994. Something Within: Religion as a Mobilizer of African-American Political Activism. Journal of Politics 56(1):42-68.

Harris, Frederick C. 1999. Something Within: Religion in African-American Political Activism. New York: Oxford University Press.

Hoggett, Paul, and Jeff Bishop. 1986. Organizing Around Enthusiasms: Patterns of Mutual Aid in Leisure. London: Comedia.

Hunt, Matthew O., and Larry L. Hunt. 2000. Regional religions? Extending the 'Semivoluntary' Thesis of African-American Religious Participation. Sociological Forum 15(4):569-594.

Leighley, Jan E. 1996. Group Membership and the Mobilization of Political Participation. Journal of Politics 58(2):447-463.

Lopata, Helen Z. 1965. The Functions of Voluntary Associations in an Ethnic Community: Polonia. Pp. 203-223 in Contributions to Urban Sociology, eds. Ernest W. Burgess and Donald J. Bogue. Chicago: University of Chicago Press.

Mangum, Maruice. 2008. Examining the Association between Church and the Party Identification of Black Americans. Politics and Religion 1(1):200-215.

McAdams, Doug. 1982. Political Process and the Development of Black Insurgency 1930-1970. Chicago, IL: University of Chicago Press.

McKenzie, Brian D. 2008. Reconsidering the Effects of Bonding Social Capital: A Closer Look at Black Civil Society Institutions in America. Political Behavior 30(1):25-43.

Morris, Aldon. 1984. The Origins of the Civil Rights Movement: Black Communities Organizing for Change. New York: Free Press.

Nelsen, Hart M., Raytah Yokley, and Anne K. Nelsen. 1971. The Black Church in America. Lexington, KY: University of Press of Kentucky.

Olsen, Marvin. 1972. Social Participation and Voting Turnout: A Multivariate Analysis. American Sociological Review 37(3):317-333.

Pollock, Phillip H. 1982. Organizations as Agents of Mobilization: How Does Group Activity Affect Political Participation? American Journal of Political Science 26(3):485-503.

Putnam, Robert D. 2000. Bowling Alone: The Collapse and Revival of American Community. New York: Simon and Schuster.

Rosenstone, Steven J., and John M. Hansen. 2003. Mobilization, Participation, and Democracy in America. New York: Longman.

Stolle, Dietlind. 1998. Bowling Together, Bowling Alone: The Development of Generalized Trust in Voluntary Associations. Political Psychology 19(3):497-525.

Streeck, Wolfgang, and Phillip C. Schmitter. 1991. Community, Market, State and Associations? The Prospective Contribution of Interest Governance to Social Order. In Markets, Hierarchies, and Networks: The Coordination of Social Life, eds. Grahame Thompson, Jennifer Frances, Rosalind Levacic, and Jeremy C Mitchell London: Sage.

Tate, Katherine. 1993. From Protest to Politics: The New Black Voters in American Elections. New York: Russell Sage Foundation.

Tate, Katherine. 1998. National Black Election Study, 1996 [Computer file]. ICPSR version. Columbus, OH: Ohio State University [producer], 1997. Ann Arbor, MI: Inter-university Consortium for Political and Social Research [distributor]. 
Timpone, Richard. 1995. Mass Mobilization or Government Intervention? The Growth of Black Registration in the South. Journal of Politics 57(2):425-442.

Tocqueville De, Alexis. [1835] 2001. Democracy in America, ed. Richard D. Hefner. New York: Signet Classic.

Verba, Sidney, and Norma Nie. 1972. Participation in America: Political Democracy and Social Equality. New York: Harper and Row.

Verba, Sidney., Kay L. Schlozman, and Henry E. Brady. 1995. Voice and Equality: Civic Voluntarism in American Politics. Cambridge, MA: Harvard University Press.

Wald, Kenneth D., Dennis E. Owen, and Samuel S. Hill, Jr. 1988. Churches as Political Communities. American Political Science Review 82(2):531-548.

Walton, Hanes, and Robert Smith. 2012. American Politics and the African-American Quest for Universal Freedom, 3rd ed. New York: Pearson Longman. 